\title{
GIS-Based Assessment of Banana Residual Biomass Potential for Ethanol Production and Power Generation: A Case Study
}

\author{
Ana Belén Guerrero ${ }^{1} \cdot$ Pedro Luis Aguado $^{1} \cdot$ Javier Sánchez $^{1}$. \\ María Dolores Curt ${ }^{1}$
}

Received: 9 June 2015/ Accepted: 26 November 2015

(C) Springer Science+Business Media Dordrecht 2015

\begin{abstract}
Purpose Banana is one of the most important fruit crops in the world. The plant bears one bunch in its life, leaving behind a large amount of agricultural residues (starchy and lignocellulosic biomass), which could be used for different purposes such as bioenergy. Ecuador is the largest exporter of banana fruits.

Methods In this work, the potential of banana residual biomass produced in the province of El Oro, Ecuador for bioenergy applications was assessed using Geographic Information Systems-GIS. The methodology included the assessment of biomass distribution, facility location, transport optimization and a novel virtual land parcel that allows for these kinds of studies in areas with lack of georeferenced information.

Results According to our approach, El Oro province has an available biomass potential of 190,102 $\mathrm{t} \mathrm{fm} \mathrm{year}^{-1}$ of starchy residual biomass and 198,602 $\mathrm{t} \mathrm{dm}_{\text {year }}{ }^{-1}$ of lignocellulosic residual biomass. Two candidate points located at $79^{\circ} 51^{\prime} 12^{\prime \prime} \mathrm{W} 3^{\circ} 11^{\prime} 21^{\prime \prime} \mathrm{S}$ and $79^{\circ} 52^{\prime} 49^{\prime \prime} \mathrm{W} 3^{\circ} 17^{\prime} 49^{\prime \prime} \mathrm{S}$ were identified for the installment of energy conversion facilities supplied with residual biomass.

Conclusions From the available potential of starchy biomass it would be possible to obtain up to 19 million liters of bioethanol per year assuming an average yield of $101.2 \mathrm{1} \mathrm{t}^{-1}$ fresh matter; while the available lignocellulosic biomass, which energy content (Lower Heating Value, moisture free biomass) was determined at $12.9 \mathrm{MJ} \mathrm{kg}^{-1}$ on average, could be used for power generation with an
\end{abstract}

Ana Belén Guerrero

anabelen.gh@gmail.com

1 Departamento de Producción Agraria, Universidad Politécnica de Madrid - UPM, 28040 Madrid, Spain installed capacity of $18 \mathrm{MW}$. Chemical characterization of the lignocellulosic biomass suggested that further studies should be undertaken regarding the potential application of these crop residues to second generation bioethanol.

Keywords GIS - Banana - Residual biomass · Bioenergy $\cdot$ Assessment

\section{Introduction}

Over the years, a growing awareness about climate change and the strong dependence on fossil fuels has arisen in the scientific community. Indeed, research about renewable energies and new technologies that replace the use of fossil fuels has increased. One of these renewable energies is bioenergy, which has been defined as the energy that can be released in combustion processes, which comes from the energy stored in a plant organism or biomass through the photosynthetic activity [1]. Biomass is considered as a distributed feedstock, and one of the major renewable resources that could be used as fuel [2]. Moreover, biofuels take advantage of solar energy stored in the biomass, and the $\mathrm{CO}_{2}$ released in its energy conversion was previously fixed from the atmosphere, making it a neutral carbon process. This fact demonstrates that the employment of biofuels in substitution of fossil fuels could be one of the ways to stop the environmental degradation caused by the increase of $\mathrm{CO}_{2}$ emissions [1].

In an energy context, biomass can be categorized according to its composition into: (1) sugary biomass, (2) starchy biomass, (3) oleaginous biomass and (4) lignocellulosic biomass. Meanwhile, according to its origin, it can be classified as natural or residual biomass. The residual biomass has the advantage that it is a waste originated from 
other productive chains than the energy crops, so it does not compete for soil or water with food crops. Therefore, lignocellulosic feedstock and discarded agro-food products do not interfere with food security [3].

Banana (Musa spp.) is a tropical, herbaceous and perennial crop of the Musaceae family, and one of the most cultivated fruit crop in the world with 106.7 million tonnes of production in 2013 [4]. The productive lifetime of banana plants from planting to harvest is from 10 to 12 months, bearing fruits only once in its life cycle [5]. After harvesting, the crop leaves behind four kinds of agricultural residues namely rachis, pseudostem, leaves and discarded bananas. A study from Brazil shows that every tonne of picked banana generates a significant amount of residual biomass, made up of $3 \mathrm{t}$ pseudostem, $150 \mathrm{~kg}$ rachis, and $480 \mathrm{~kg}$ leaves [6], in fresh matter.

Once the harvest is completed, the lignocellulosic biomass (pseudostem, leaves and rachis) is usually left on the ground to be used as organic matter or mulching, but in some cases it could turn out as an infectious focus or it is eliminated in waste dumps. A fraction of this lignocellulosic biomass could be used as fiber or pulped for the paper industry, ropes, wrapping food, boards or textile. Besides this, the starchy residual biomass is produced in the postharvest stage, in which the bananas that do not meet the standards for commercialization are rejected. The proportion of discarded bananas varies from about $10-30 \%$ of the total banana production [7]. A small proportion of the starchy biomass is used as animal feed and also for banana flour, but most of it is eliminated on the ground or in dumps [8]. Furthermore, there are no statistical estimates of the final use of these residues. The bioconversion of this residual biomass into biofuels or energy could replace a significant proportion of fossil fuels and diversify the energy mix [9]. In spite of this, the agricultural residues from the banana crop have been hardly considered for energy production so far [10].

Nowadays, bioenergy systems are gaining relevance worldwide, and the production of biofuels from agricultural residues has become more and more attractive for researchers. For instance, Graefe et al. [8] showed the environmental viability of using discarded bananas for ethanol production. Clarke et al. [11] measured the methane yield and rate of digestion of discarded bananas, proving that there are no technical barriers to digest banana wastes at a commercial scale. In addition, some researchers have studied the potential of starchy biomass for first generation ethanol production, which appears to be a very promising activity due to its high ethanol yield on a dry weight basis compared to other residues $[8,12,13]$.

In the case of the lignocellulosic biomass, Abdullah et al. [5] showed the feasibility of using banana crop wastes as feedstock for thermochemical processes, showing similar thermal behavior to other biomasses already used for generation of renewable energy in the pyrolysis pathway. Santa-Maria et al. [10] assessed the feasibility of producing second generation ethanol from the lignocellulosic banana waste, showing the large potential for cellulosic ethanol production due to the abundance of the feedstock. Most of the researchers have focused their efforts to improve the yield and reduce production costs $[10,13,14]$. Major crop residues such as wheat straw, rice hulls, corn stover and wood chips, have been largely studied as a feedstock for bioenergy, but little is known about the energy conversion of major non-staple crops, such as banana crop. Nevertheless, few studies have been made on the amount and availability of banana residual biomass for energy uses [15]. Given the abundance and the widespread distribution of banana in tropical and subtropical regions, the supply chain of its residual biomass for bioenergy applications should be explored [10].

Ecuador is the largest exporter of banana, contributing with $29 \%$ of the worldwide exports [16]. Harvesting is carried out all year round. However, there is a high season (January-April) and a low season (May-December). The average yield is $33.78 \pm 4.06 \mathrm{t} \mathrm{ha}^{-1}$ fresh matter (fm), depending on soil fertility and farming practices [17]. The country has an average cultivated area of 224,137 ha dedicated to banana cultivation. The $81 \%$ of this area is distributed between the provinces of Los Ríos, Guayas and El Oro, which own 39, 36 and $20 \%$ of the national production, respectively [18]. However, to the best of our knowledge, only one research on the production of agricultural residues of banana for second generation ethanol has been published in Ecuador [19]. In that work, banana residues are recognized as the most important agricultural residue of the country with a promising future due to its quantity, centralized localization and availability. Nevertheless, there is a lack of formal information. Thus, it is essential to assess the availability of this residual biomass and its supply chain in order to know the potential of this biomass as an energy source.

The feasibility of emplacing an energy conversion plant for the energy use of agricultural residues depends on the availability and continuous supply of feedstock, demanding a good relation between the raw material producers and the processing plant. Furthermore, the development of an accurate logistical supply chain is needed in order to demonstrate economic and environmental sustainability [20]. Since the availability of the biomass is site-specific and depends on its geographical distribution, Geographic Information Systems-GIS have been considered as an accurate tool to estimate the available agricultural residue potential of a specific area. It has been proven that GIS allows for a simple and precise quantification of available resources in a specific target area [21]. 
The aim of this work is to determine the potential availability of lignocellulosic and starchy biomass generated from the banana crop in El Oro, Ecuador for the production of bioethanol and for power generation through combustion. This study comprised of assessment of the potential production of residual biomass of the banana crop through GIS tools, site suitability of conversion plants and determination of plants production capacity, spatially optimized biomass collection areas and transportation distances.

\section{Materials and Methods}

\section{Study Area}

The province of El Oro is located in the extreme southwest of Ecuador, next to the Pacific Ocean, at $80^{\circ} 14^{\prime} 42^{\prime \prime}$ and $79^{\circ} 25^{\prime} 50^{\prime \prime} \mathrm{W}$ longitude and $3^{\circ} 3^{\prime} 16^{\prime \prime}$ and $3^{\circ} 50^{\prime} 1^{\prime \prime} \mathrm{S}$ latitude. The total geographical area of this province is $5767 \mathrm{~km}^{2}$. A tropical dry megathermal climate predominates in the province with an average temperature of $25^{\circ} \mathrm{C}$ throughout the year. El Oro has $59,914 \pm 3836$ ha dedicated to the banana cultivation [18] which are concentrated at the northwest zone of the province (Fig. 1), with an average production of $36.64 \pm 4.72 \mathrm{t} \mathrm{ha}^{-1}$.

\section{Data Source}

Crop statistics of Ecuador available at the Ministry of Agriculture [18] and the National Institute of Statistics [17] are the major data sources of banana production, cropping area and yield. This information was used to estimate the residual biomass availability of the banana crop (Table 1). Mean values of the last 6 years were considered in order to minimize the variance.

Spatial information used in this work was compiled from the official databases detailed below:

- Map of the land use capacity $(1: 250,000)$ from the geoportal of the Ministry of Agriculture [22].

- Road map and climate map (1:200,000) from the official web site of El Oro government [23].

- Map of electrical substations: it was developed from the geoportal information of the National Electricity Council of Ecuador [24].

- Maps from the Military Geographical Institute [25] and Google Earth were used to improve and update the information of the abovementioned layers.

\section{Assessing the Production of Residual Biomass}

All spatial related tasks were performed using $\operatorname{ArcGIS}^{\circledR} 10$ software by ESRI, Redlands, California. The first step of
Fig. 1 Target study area El Oro-Ecuador, highlighted the distribution of the banana cultivation

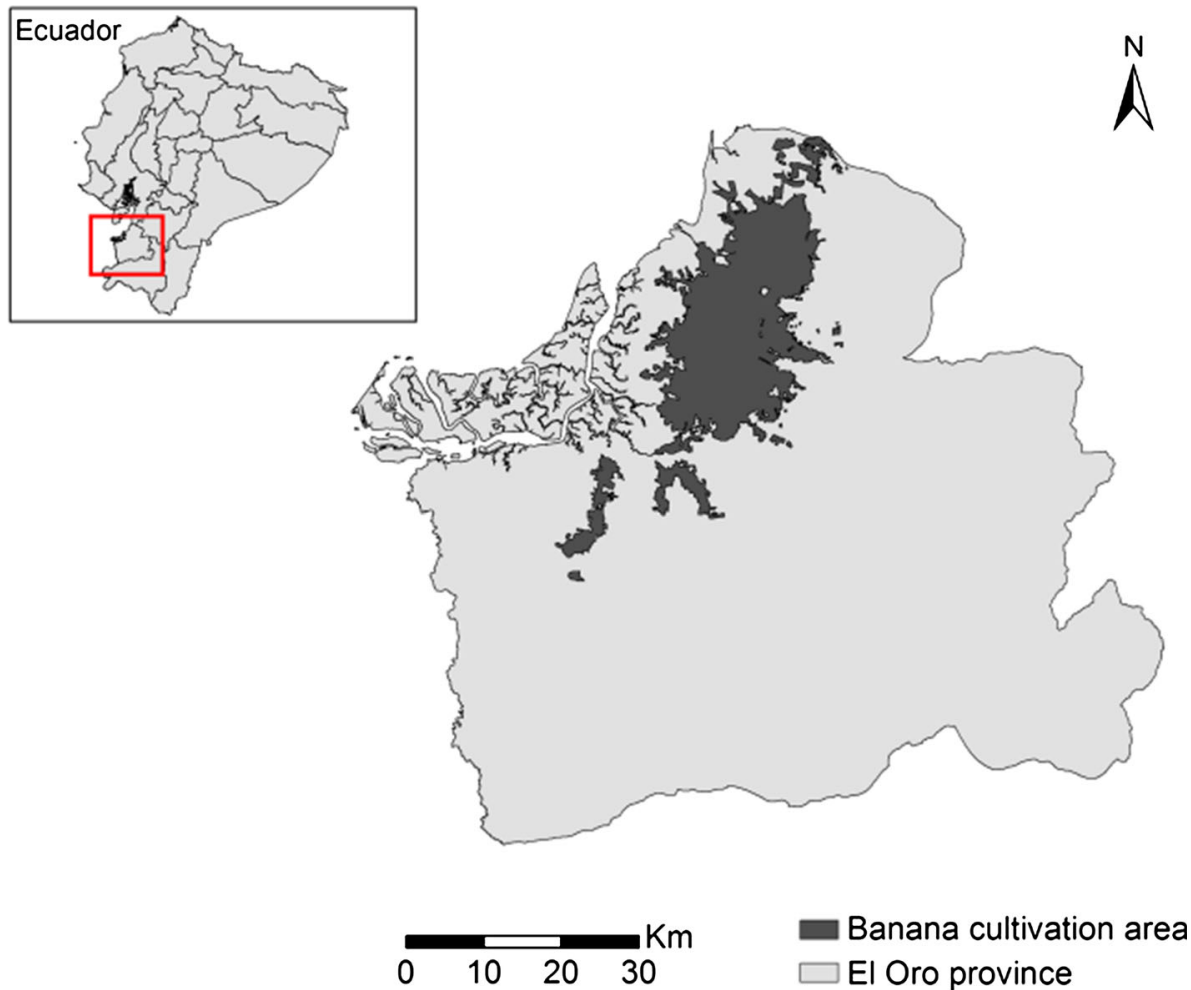


Table 1 Banana statistics of El Oro province [18]

\begin{tabular}{llll}
\hline Year & Banana area (ha) & Production $(\mathrm{t})$ & Yield $\left(\mathrm{t} \mathrm{ha}^{-1}\right)$ \\
\hline 2008 & 61,801 & $2,104,645$ & 34.04 \\
2009 & 56,887 & $1,861,662$ & 32.71 \\
2010 & 57,657 & $1,892,647$ & 32.81 \\
2011 & 55,163 & $2,443,673$ & 44.29 \\
2012 & 63,883 & $2,269,901$ & 35.52 \\
2013 & 64,093 & $2,594,000$ & 40.47 \\
Mean & $59,914( \pm 3836)$ & $2,194,421( \pm 295,750)$ & $36.64( \pm 4.72)$
\end{tabular}

the potential biomass assessment was the analysis of the distribution area of the banana cultivation in the target zone from the land use map, and the statistical information of the crop. With these data the Theoretical Biomass Potential $(T B P)$ which is the total amount of agricultural residues generated in a target area, and the Available Biomass Potential $(A B P)$ that represents the amount of biomass that can be technically and economically harvested and used for energy purposes [26] were estimated (Fig. 2).

In this work TBP was estimated from the value of banana production and the Residue to Product Ratio (RPR), since the amount of agricultural residue is directly related to the crop production [27]. National statistical data of yields and values of RPR of lignocellulosic and starchy biomass were stored in a GIS database to estimate the total annual production of agricultural residues of the banana crop in El Oro province.

For the estimation of ABP, a delimitation of the area that could be used was conducted. Taking into account that there was a lack of geo-referenced information about the distribution of the agricultural land parcel system, a layer of virtual distribution was developed in order to identify distribution plots. For the development of this layer, junctions of main roads were taken as the points for building the Thiessen polygons. The obtained polygons were then intersected to the land use layer in order to get a virtual land parceling that typifies small holdings. A Thiessen polygon represents an area of influence around a sample point, so that any location inside the polygon is closer to that point than any of the other sample points. In this study, those points were taken as the demand points (production points) and each polygon represented a small holding. The virtual land parcel layer was developed to better proceed with the subsequent location-allocation process (see "Location of Biomass Conversion Facilities" section) and thus, be able to optimize the supply area of each biomass conversion plant.

\section{Location of Biomass Conversion Facilities}

With the aim of achieving economic sustainability, the ABP estimation included the following two restrictions of the banana cultivation area: (1) the location of the processing plant had to be near to an electric substation and (2) the location of the conversion facility should cover an average radius of $10 \mathrm{~km}$ to the production plots [8, 28]. Two types of conversion plants were considered in this work: a bioethanol plant based on banana starchy residues and a power plant fed with lignocellulosic biomass from the banana crop. Since the crop area that would supply the feedstocks would be the same, it was assumed that both types of plants would be installed at the same location or candidate point.

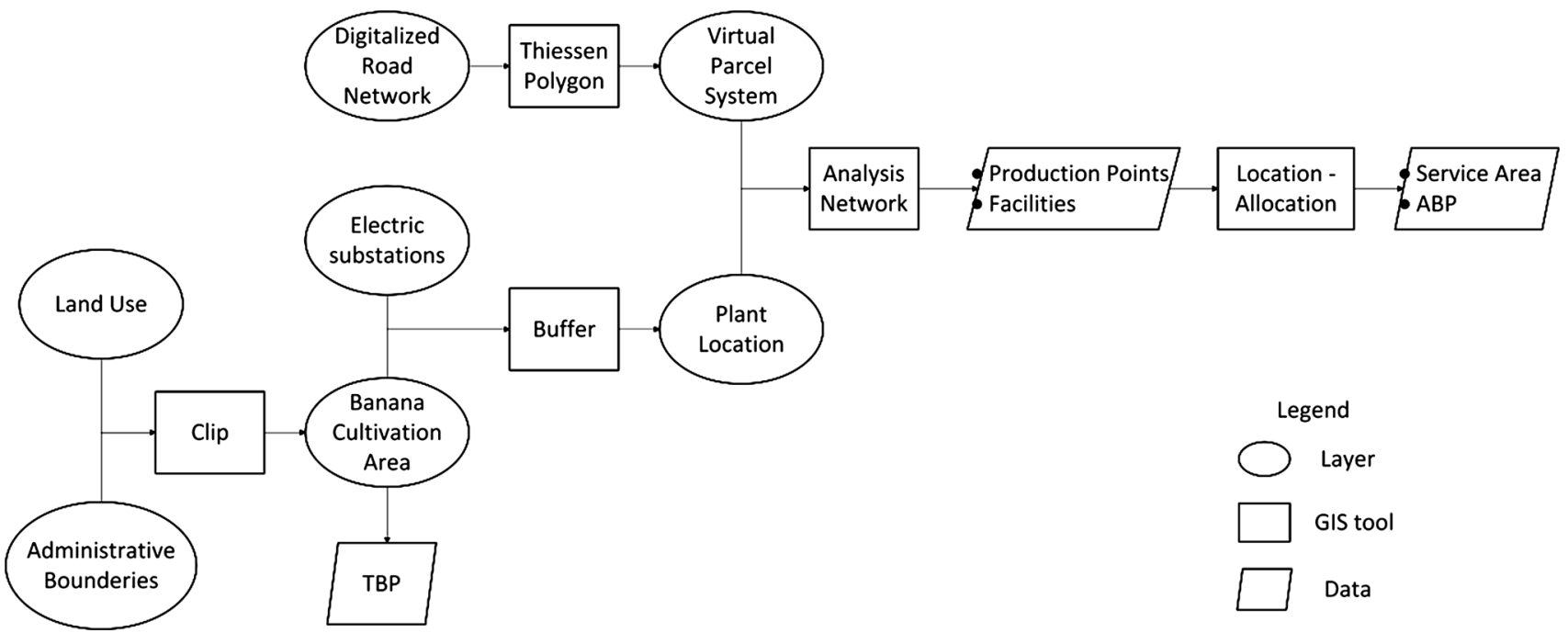

Fig. 2 Data flow diagram of GIS process 
Biomass availability in the nearby area of the conversion plants (candidate point) was estimated using the Network Analyst extension of the ArcGIS software. The service area for each conversion plant was calculated based on the premise that the maximum road distance (RD) from the parcel to the nearest candidate (facility) should not exceed a certain value. The maximum distance was calculated by comparing the costs of the production chain to the market price of the final product. This comparison was modeled according to Eq. 1 for the starchy biomass and to Eq. 2 for the lignocellulosic biomass.

$R D=\frac{((1-\% \text { profit }) \times B)-C-(P \times Y)}{T}$

$R D=\frac{((1-\% \text { profit }) \times B)-C-(A \times L H V)}{T}$

where $\mathrm{RD}$ is the maximum road distance $(\mathrm{km}), \mathrm{Y}$ is the ethanol yield $\left(1 \mathrm{t}^{-1}\right)$, B is the market price including a profit between $10-15 \%\left(\$ 1^{-1}\right.$ bioethanol in Eq. $1, \$ \mathrm{kWh}_{\mathrm{e}}$ in Eq. 2), $\mathrm{C}$ is the cost of biomass $\left(\$ \mathrm{t}^{-1}\right), \mathrm{P}$ is the production cost at the conversion plant $\left(\$ \mathrm{t}^{-1}\right), \mathrm{A}$ is the energy conversion cost $\left(\$ \mathrm{t}^{-1}\right)$, LHV is the Low Heating Value (expressed in $\mathrm{kWh} \mathrm{kg}^{-1}$ ), and $\mathrm{T}$ is the transportation cost $\left(\$ \mathrm{t}^{-1} \mathrm{~km}^{-1}\right)$.

Data used for energy conversion costs (Table 2) were taken from the literature and are referred to different kinds of biomass and geographical locations because of the lack of specific information on banana residues. For the calculation of the bioethanol production costs and its economic viability, the actual market price set at $0.70 \$ 1^{-1}$ in Ecuador (for the mix of ecopaís gasoline E5) in 2014 was assumed. Meanwhile, $0.0967 \$ \mathrm{kWh}_{\mathrm{e}}^{-1}$ was assumed as the market price for power generation with renewable energies [29]. Thus, the premise of our approach was that the costs

Table 2 Bioethanol and power generation production costs

\begin{tabular}{lll}
\hline Item & Bioethanol & Power \\
\hline Biomass & $20 \$ \mathrm{t}^{-1}$ & $15 \$ \mathrm{t}^{-1}$ \\
Transformation cost $^{-1 \mathrm{a}}$ & $0.39 \$ \mathrm{l}^{-1 \mathrm{a}}$ & $0.08 \$ \mathrm{kWh}^{\mathrm{b}}$ \\
Transportation $^{\mathrm{c}}$ & $0.0675 \$ \mathrm{t}^{-1} \mathrm{~km}^{-1}$ & $0.0675 \$ \mathrm{t}^{-1} \mathrm{~km}^{-1}$ \\
Market price $^{\text {Yield }}$ & $0.7 \$ \mathrm{l}^{-1}$ & $0.0967 \$ \mathrm{kWh}_{\mathrm{e}}^{-1 \mathrm{~d}}$ \\
Low heating value $^{\mathrm{f}}$ & $101.2 \mathrm{t} \mathrm{t}^{-1} \mathrm{fm}$ & - \\
\hline
\end{tabular}

a Average data [42, 43]

b According to IRENA [39]

${ }^{c}$ For distances $<400 \mathrm{~km}$

d According to Conelec [29]

e Average data [8, 12]

${ }^{\mathrm{f}}$ See Table 4 of feedstock, transportation and energy conversion should be lower than this value.

A location-allocation analysis was conducted in order to estimate the optimal location of the conversion plants. Then, the service area was assessed once that each biomass production point had been assigned to its closest facility. For this purpose, the road network in the study area was digitalized and used to create a geodatabase network dataset. The location-allocation analysis was performed considering a minimize impedance problem-type to identify locations for target facilities of energy conversion. After that, the area of banana that would supply residual biomass to each plant and subsequently, the potential amount of residual biomass, were calculated. The value obtained was used for estimating the capacity of the energy conversion plants along with the RPR.

\section{Energy and Chemical Characterization of Lignocellulosic Biomass}

The residual biomass fractions: rachis, pseudostem and leaves, were randomly sampled from old banana plants of the genomic group AAA subgroup Cavendish in Ecuador. Then, they were taken to laboratory to be dried and finally, ground to pass through a $1 \mathrm{~mm}$ sieve.

The higher heating value $\left(\mathrm{HHV}_{0}\right)$ of the lignocellulosic biomass was measured using a Leco AC 3500 calorimeter according to the standard for solid biofuels UNE-EN 14918 of AENOR. The analysis was developed in duplicate. Lower heating value $\left(\mathrm{LHV}_{0}\right)$ was calculated from the $\mathrm{HHV}_{0}$ and the hydrogen content, according to Eq. 3.

$L H V_{0}\left(\mathrm{~kJ} \mathrm{~kg}^{-1}\right)=H H V_{0}\left(\mathrm{~kJ} \mathrm{~kg}^{-1}\right)-206 \times \% H$

Chemical characterization of the lignocellulosic biomass was performed using the standard biomass laboratory analytical procedures (NREL/TP-510-42620, NREL/TP510-42619, NREL/TP-510-42618 and NREL/TP-51042622) of the National Renewable Energy LaboratoryNREL [30].

\section{Results and Discussion}

The proposal of using residual biomass of banana crop in El Oro province for bioenergy entails several advantages including: (1) the crop concentration in the study area (Fig. 1), minimizing the energy needed for biomass transportation [1]; (2) the large cultivation area dedicated to this crop; and (3) the continuous production of agricultural residues along the year [10]. Thus, the supply of biomass can be steady and it does not depend on a specific season of the year. 


\section{Theoretical Biomass Potential}

The GIS based assessment of the TBP, using maps of administrative boundaries, land use and national statistics, allows one to calculate the total biomass produced and its distribution in order to choose the location of energy conversion plants [26]. Therefore, TBP was estimated from the values of: (1) cultivation area, (2) crop yield and (3) residue-to-product ratios. The latter were based on literature data. Mean RPR calculated for the lignocellulosic biomass was $2.13 \pm 0.23$ tonnes of residue per tonne of economic product $\left(\mathrm{t} \mathrm{t}^{-1}\right)$, and for the starchy biomass $0.21 \pm 0.09 \mathrm{t} \mathrm{t}^{-1}$ (Table 3). From these values, the production of residual biomass was calculated for each year.

Mean yield of banana crop of the last 5 years in El Oro province was calculated and taken as a reference value for this work given the fact that both yields and crop area vary from year to year. Thus, the potential production of residual biomass was estimated at $78.04 \pm 10.05 \mathrm{t} \mathrm{ha}^{-1}$ for the lignocellulosic biomass and $7.69 \pm 0.99 \mathrm{t} \mathrm{ha}^{-1}$ for the starchy biomass. It is difficult to make an accurate estimation of this production, since it is influenced by soil conditions, farming practices, cultivar and climate conditions [15, 27]. Consequently, considering an average area of 59,914 ha dedicated to banana cultivation in El Oro province, the estimated TBP would reach up to 461,002 and $4,675,880 \mathrm{t} \mathrm{year}^{-1}$ for the starchy and lignocellulosic biomass, respectively.

\section{Virtual Land Parceling}

The biomass availability assessment and the emplacement of the biomass conversion plant are important factors due to high logistical costs that the biomass supply to the conversion plant may entail. According to Sing et al., one of the accurate ways of performing this assessment is using GIS since this tool allows one to manage and analyze multi-spatial and temporal data [31, 32].
When this work was developed, the cadastral mapping of the banana crop in El Oro province did not exist, so a virtual land parcel layer was developed using ArcGIS tools (Fig. 4a). This process of land subdivision involves splitting up a larger land tract into smaller subspaces known as parcels [33].

\section{Location of Conversion Facilities}

The next step to determine the ABP in the area of study was the site selection of the conversion plants, applying the restrictions mentioned in the Materials and Methods section. In El Oro province the crop is concentrated in one area, which makes the transportation of the residual biomass easier and diminishes the costs of power distribution. Thus, two conversion plants were located near to the power substations established in the study area, where they would cover a service area of about 40,000 ha. The site of each conversion plant was defined as the centroid of the cluster area covered by a radius of $10 \mathrm{~km}$ around the substations [8] (Fig. 3b).

\section{Available Biomass Potential}

Once the optimal location for the two energy conversion plants was established and the virtual land parcel subdivision was done, a discrete location-allocation model based on the road network was developed. The location-allocation, an ArcGIS Network Analyst tool, finds the shortest path from demand points (production points) to the nearest facility (plant), considering factors such as the number of facilities available, transportation cost, and the maximum impedance from a facility to a point. This tool minimizes the sum of the weighed distances from the demand points to a facility and thus minimizes the unit cost of energy [20, 28]. In this study the maximum impedance used was of $20 \mathrm{~km} \mathrm{RD} \mathrm{(Eqs.} \mathrm{1,} \mathrm{2),} \mathrm{which} \mathrm{is} \mathrm{considered} \mathrm{adequate} \mathrm{due} \mathrm{to}$ the distribution of the banana cultivation area and the location of the conversion plants. This procedure was also

Table 3 Literature based-data of RPR for lignocellulosic and starchy residual biomass of banana crop

\begin{tabular}{|c|c|c|c|c|c|}
\hline \multicolumn{3}{|l|}{ Lignocellulosic biomass } & \multicolumn{3}{|l|}{ Starchy biomass } \\
\hline Reference & Year of publication & $\mathrm{RPR} f \mathrm{fm}\left(\mathrm{t} \mathrm{t}^{-1}\right)$ & Reference & Year of publication & $\operatorname{RPR} f m\left(\mathrm{t} \mathrm{t}^{-1}\right)$ \\
\hline Amoo and Hall [44] & 1999 & 2.00 & Hammond et al. [12] & 1996 & 0.25 \\
\hline Jingura et al. [45] & 2008 & 2.00 & Tock et al. [9] & 2010 & 0.30 \\
\hline \multirow[t]{3}{*}{ Tock et al. [9] } & 2010 & 2.40 & Graefe et al. [8] & 2011 & 0.08 \\
\hline & & & Robinson and Galán [7] & 2012 & 0.20 \\
\hline & & & Mean \pm standard deviation & & $0.21 \pm 0.094$ \\
\hline Mean \pm standard deviation & & $2.13 \pm 0.23$ & & & \\
\hline
\end{tabular}





Fig. 3 a Virtual land parcel of the area where the biomass could be harnessed, b potential area that might be covered by the two candidate points

used in other studies in which the maximum impedance resulted in $25 \mathrm{~km}$ [34]. Drawbacks of longer transportation distances include the energy consumption associated with transportation and the high biomass moisture content.

Every land parcel that had a RD to a facility candidate lower than $20 \mathrm{~km}$ was selected and then assigned to the nearest facility (Fig. 4a). Results showed that the biomass produced in 17,052 and 21,552 ha (service area) could be allocated to the north and south conversion plants, respectively (Fig. 4b). Dismissing $36 \%$ of the biomass produced in that estimated area which could be dedicated to agricultural harnessing [6], El Oro has an ABP in a fresh matter basis of $190,102 \mathrm{t}^{\text {year }}{ }^{-1}$ of starchy biomass and $1,928,179 \mathrm{t} \mathrm{year}^{-1}$ of lignocellulosic biomass for energy applications.

\section{Plant Capacity}

\section{Starchy Biomass: First Generation Bioethanol}

Discarded bananas are considered as a good feedstock for bioethanol production because it is a starch-based biomass that mostly contains carbohydrates associated with small amounts of fiber. The banana fruit (pulp and peel) is made of $49 \%$ starch and $3 \%$ sugars [13].

For bioethanol production, carbohydrates must be first converted into simple sugars (sacharification) and then fermented into ethanol. The predominant carbohydrate is the starch, but it rapidly converts to sugar during ripening [12]. The sacharification can be undertaken by two methods: chemical (by means of acids) or biochemical (by means of enzymes), being the cheapest way the use of chemicals to alter the structure of polysaccharides. The advantage of the banana crop is that it allows a steady supply of starchy biomass to the bioethanol plant throughout the year, due to the characteristics of its productive cycle.

The available starchy biomass was calculated considering the actual accessible area and dismissing $36 \%$ of the biomass that could be used in other activities [6]. Under such conditions, the service area of the northern plant could provide $83,971 \mathrm{t} \mathrm{year}^{-1}$, whereas the area of the southern plant could render 106,131 $\mathrm{t}_{\text {year }}{ }^{-1}$ of rejected banana fruits. With all this biomass, El Oro province would be able to produce 19 million 1 year $^{-1}$ of bioethanol assuming an average conversion ratio of $101.21 \mathrm{t}^{-1} \mathrm{fm}[8,12]$. The 

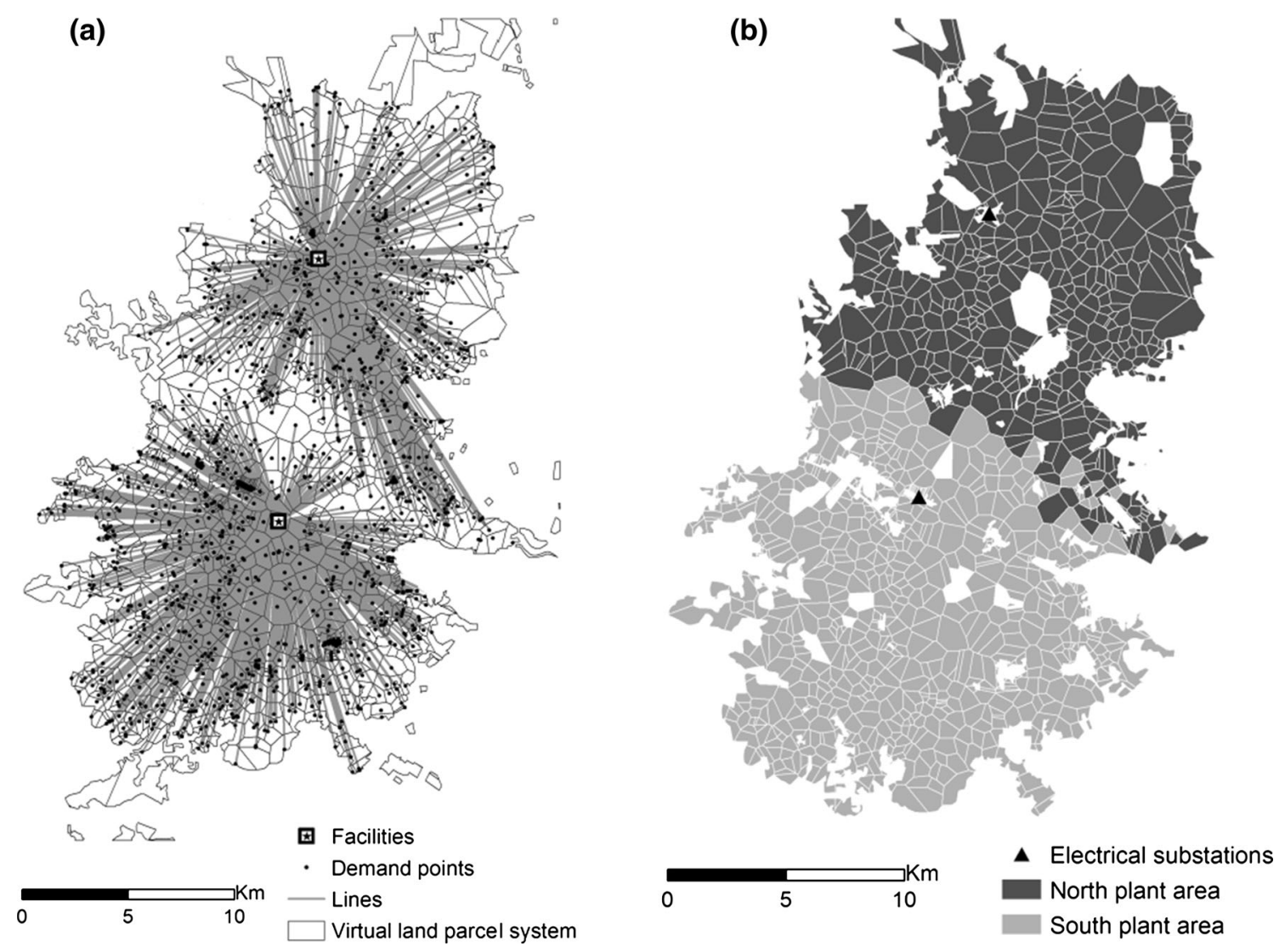

Fig. 4 a Allocation of the available biomass to the nearest conversion plant, $\mathbf{b}$ area that would provide of biomass to each conversion plant

average conversion ratio of rejected bananas to ethanol used in this study is comparable to other feedstock such as cassava [35]. According to Hammond et al. [12], Velásquez-Arredondo et al. [13] and Graefe et al. [8] discarded bananas are considered to be a feedstock energetically viable due to its positive energy balance showing that the use of this feedstock can be economic and environmentally sustainable.

The production of bioethanol from rejected banana could help to accomplish the $5 \%$ target set by the Ecuadorian government for the use of bioethanol in regular gasoline for vehicles in the whole country by 2020 . According to Carvajal et al. [19] Ecuador's ethanol fuel needs were 121 million liters in 2010 while the ethanol production reached was 4.5 million, only meeting $3.7 \%$ of the needs of the country. If the amount of rejected banana fruits produced in El Oro were intended for bioethanol production, the coverage of the bioethanol demand of Ecuador would increase to $19.6 \%$.

\section{Lignocellulosic Biomass: Thermal Conversion for Electricity}

The lignocellulosic residual biomass could be used as a feedstock for bioenergy following different technologies, such as Biomass to Liquid fuel (BTL), combustion, or power generation, based on the content in structural carbohydrates and calorific value. Results of the chemical composition and higher heating value of the lignocellulosic fractions are shown in Table 4. Depending on the fraction studied, the content of holocellulose could vary from 35 to $50 \%$. These values are similar to the ones reported by Oliveira et al. [36] and Santa-Maria et al. [10], who also studied the potential of agricultural residues of banana plants as a non-wood renewable source. These authors stated that further studies would be needed to ensure the feasibility of the energy applications of banana residual biomass and to enhance its use at an industrial scale.

In our approach, the amount of available lignocellulosic biomass was calculated assuming the same crop area as found for the starchy biomass (see previous section on starchy biomass). According to that, facilities located at the north and south candidate points could receive up to $851,707 \mathrm{t}$ and 1,076,472 $\mathrm{t} \mathrm{fm}$ of lignocellulosic biomass per year, respectively, for power generation through thermal conversion. In terms of dry matter it would be equivalent to $198,602 \mathrm{t} d \mathrm{~m}$ of lignocellulosic biomass per year, assuming $89.7 \%$ moisture content.

The average lower heating value of the lignocellulosic biomass on dry matter basis was $12.9 \mathrm{MJ} \mathrm{kg}^{-1}$. It was 
Table 4 Chemical composition of banana biomass as determined in this work and its comparison with data reported in scientific literature

\begin{tabular}{|c|c|c|c|c|c|c|c|}
\hline Reference & $\mathrm{LHV}_{0}\left(\mathrm{MJ} \mathrm{kg}^{-1}\right)$ & Cellulose (\%) & Hemicellulose (\%) & Lignin $(\%)$ & Ash (\%) & Extractives (\%) & Total \\
\hline \multicolumn{8}{|l|}{ Rachis } \\
\hline This work & $10.0( \pm 0.1)$ & $26.4( \pm 1.0)$ & $10.2( \pm 0.7)$ & $9.4( \pm 0.3)$ & $26.6( \pm 0.3)$ & $19.9( \pm 1.1)$ & 91.0 \\
\hline Oliveira et al. [36] & - & 28.4 & 7.5 & 10.5 & 26.8 & 17.6 & 90.8 \\
\hline Gabhane et al. [14] & - & 36.1 & 7.0 & 16.43 & 26.8 & - & 86.4 \\
\hline Abdullah et al. [5] & 11.7 & 39.8 & 27.8 & 18.0 & 20.6 & 6 & 112.2 \\
\hline Velásquez et al. [13] & 12.8 & - & - & - & - & - & - \\
\hline \multicolumn{8}{|l|}{ Pseudostem } \\
\hline This work & 10.4 & $38.0( \pm 0.5)$ & $8.7( \pm 0.1)$ & $8.9( \pm 0.2)$ & $17.6( \pm 0.0)$ & $24.1( \pm 3.2)$ & 96.0 \\
\hline Oliveira et al. [36] & - & 37.3 & 11.4 & 13.3 & 19.0 & 12.6 & 93.6 \\
\hline Gabhane et al. [14] & - & 44.3 & 22.0 & 9.6 & 14.0 & & 89.9 \\
\hline Abdullah et al. [5] & 14.5 & 44 & 17.5 & 37.3 & 11.0 & 9.7 & 119.5 \\
\hline Saraiva et al. [37] & 14.2 & - & - & - & - & - & - \\
\hline \multicolumn{8}{|l|}{ Leaves } \\
\hline This work & $16.5( \pm 0.1)$ & $21.9( \pm 0.5)$ & $12.8( \pm 0.2)$ & $21.5( \pm 0.2)$ & $15.7( \pm 0.2)$ & $18.0( \pm 0.6)$ & 88.6 \\
\hline Oliveira et al. [36] & - & 20.4 & 8.6 & 24.3 & 19.4 & 16.1 & 88.8 \\
\hline Gabhane et al. [14] & - & 32.6 & 12.0 & 21.8 & 19.4 & - & 85.8 \\
\hline Fernandes et al. [6] & 18.5 & 26.7 & 25.8 & 17.0 & 8.7 & - & 78.2 \\
\hline
\end{tabular}

calculated as a weighed mean of the results of LHV of every lignocellulosic fraction except for the rachis, which was dismissed because of: (1) its high ash content (see Table 4), and (2) the fact that this residue is generated in the post-harvest stage. The weighed LHV mean is referred to dry matter basis, estimating a share of $59 \%$ pseudostem and $41 \%$ leaves. According to Abdullah et al. [5], Velásquez-Arredondo et al. [13], Fernandes et al. [6], and Saraiva et al. [37] the LHV of lignocellulosic banana residues varies depending on the chemical composition of each fraction and it could be in the range of $11-20 \mathrm{MJ} \mathrm{kg}^{-1}$.

Banana leaves are the feedstock that yielded higher values of LHV, which is attributed to their content in lignin. Oliveira et al. [36] obtained similar values for the characterization of banana biomass and suggested that the high ash content in the rachis was probably due to the important function of the rachis in nutrient transportation, giving rise to higher levels of potassium, calcium and silicum salts. Also, it was shown that a high amount of ash is soluble; according to Cordeiro et al. [38], $50 \%$ of the ash can be extracted by washing; so this value could increase or decrease depending on the field management of the residue.

From the results of LHV and the estimates of available lignocellulosic biomass $\left(198,602 \mathrm{t} \mathrm{dm} \mathrm{year}^{-1}\right.$ of pseudostem and leaves), assuming that the biomass is supplied to the power plants with $20 \%$ moisture content, a $21 \%$ power conversion efficiency $[9,39]$ and $7920 \mathrm{~h}$ annual operation per power plant, the potential capacity of the two power plants considered in this work (north and south) could be up to $18 \mathrm{MW}$. The annual mean power consumption of each family in El Oro is $1572 \mathrm{~kW} \mathrm{~h} \mathrm{[40],} \mathrm{and}$ the number of families in the province is 163,293 [41]. Both conversion plants could cover up to $55 \%$ of El Oro families' power needs.

Fernandes et al. [6] suggested that the banana residues could be used for power generation and that this application would significantly contribute to reduce waste volumes and environmental impacts caused by their disposal. However, it should be pointed out that the value found for $\mathrm{LHV}_{0}$ is lower than that of other biomass feedstocks used for power generation and that the ash content is high. On the other hand, evidence has been provided that the holocellulose content of this type of lignocellulosic biomass is high. Therefore, it is suggested that this feedstock should be studied for second generation ethanol production.

\section{Conclusions}

El Oro province has a great potential for the production of biofuels from agricultural residues. Banana is the major crop in El Oro and generates residual biomass of two types: starchy and lignocellulosic. From the available starchy biomass up to 19 million liters of bioethanol per year could be produced; besides, the lignocellulosic residual biomass could be used for power generation with a potential installed capacity of $18 \mathrm{MW}$. Results of chemical 
characterization suggested that the lignocellulosic biomass could be dedicated to second generation bioethanol as well. Further studies should be undertaken to find out which technology would better fit within the characteristics of this biomass.

GIS information constitutes the basis for the assessment of the ABP and helps to understand the spatial distribution of the biomass. In addition, this tool is useful to study the supply chain and to optimize the site selection of a conversion facility in terms of biomass distribution, transformation and transportation costs. The studied GIS methodology uses the existing road network, which provides accurate transportation distance information that could be used for cost analysis and environmental impact assessment. Furthermore, the virtual land parcel system is considered to be a useful methodology for countries and regions with lack of spatial information. It helps to establish a pattern of production points, which allows the study of the supply chain, providing a method that could be applied in different countries.

Finally, the harnessing of agricultural residues could help reduce both the volume of residues and their environmental impact, caused by organic degradation. Moreover, the economic use of the residual biomass could enhance the development of small farmers of the region who could earn an extra income. Indeed, this activity could contribute to a sustainable development of the rural area. Taking into account that food security is a global priority, the harnessing of residual biomass for bioenergy would not affect food security and could improve the well-being of rural people.

Acknowledgments The authors would like to acknowledge the Agroenergy Group of Universidad Politécnica de Madrid-UPM of Spain, Universidad de las Fuerzas Armadas-ESPE of Ecuador, and the Biofuel Unit of the Research Centre for Energy, Environment and Technology_CIEMAT of Spain.

\section{References}

1. Fernández, J.: Energía de la Biomasa. In: Martínez, J.M. (ed.) La Energía en sus Claves, pp. 398-445. Madrid (2004)

2. Hiloidhari, M., Baruah, D.C.: Crop residue biomass for decentralized electrical power generation in rural areas (part 1): investigation of spatial availability. Renew. Sustain. Energy Rev. 15, 1885-1892 (2011)

3. Kim, S., Dale, B.E.: Global potential bioethanol production from wasted crops and crop residues. Biomass Bioenergy 26, 361-375 (2004)

4. FAO: FAOSTAT. http://faostat3.fao.org/browse/Q/QC/E (2014). Accessed 25 Feb 2015

5. Abdullah, N., Sulaiman, F., Azma, M., Taib, R.M.: Characterization of banana (Musa spp.) plantation wastes as a potential renewable energy source. Int. J. Biol. Vet. Agric. Food Eng. 8, 782-786 (2014)
6. Fernandes, E.R.K., Marangoni, C., Souza, O., Sellin, N.: Thermochemical characterization of banana leaves as a potential energy source. Energy Convers. Manag. 75, 603-608 (2013)

7. Robinson, J., Galán, V.: Plátanos y bananas. Mundi-Prensa, Madrid (2012)

8. Graefe, S., Dufour, D., Giraldo, A., Muñoz, L.: Energy and carbon footprints of ethanol production using banana and cooking banana discard: a case study from Costa Rica and Ecuador. Biomass Bioenergy 35, 2640-2649 (2011)

9. Tock, J.Y., Lai, C.L., Lee, K.T., Tan, K.T., Bhatia, S.: Banana biomass as potential renewable energy resource: a Malaysian case study. Renew. Sustain. Energy Rev. 14, 798-805 (2010)

10. Santa-Maria, M., Ruiz-Colorado, A., Cruz, G., Jeoh, T.: Assessing the feasibility of biofuel production from lignocellulosic banana waste in rural agricultural communities in Peru and Colombia. Bioenergy Res. 6, 1000-1011 (2013)

11. Clarke, W.P., Radnidge, P., Lai, T.E., Jensen, P.D., Hardin, M.T.: Digestion of waste bananas to generate energy in Australia. Waste Manag. 28, 527-533 (2008)

12. Hammond, J.B., Egg, R., Diggins, D., Coble, C.G.: Alcohol from bananas. Bioresour. Technol. 56, 125-130 (1996)

13. Velásquez-Arredondo, H.I., Ruiz-Colorado, A.A., De Oliveira, S.: Ethanol production process from banana fruit and its lignocellulosic residues: energy analysis. Energy 35, 3081-3087 (2010)

14. Gabhane, J., William, S.P.M.P., Gadhe, A., Rath, R., Vaidya, A.N., Wate, S.: Pretreatment of banana agricultural waste for bioethanol production: individual and interactive effects of acid and alkali pretreatments with autoclaving, microwave heating and ultrasonication. Waste Manag. 34, 498-503 (2014)

15. Garcia, M.J.C., Machimura, T., Matsui, T.: Optimizing plant allocation for bioethanol production from agro-residues considering $\mathrm{CO}_{2}$ emission and energy demand-supply balance: a case study in Ecuador. Waste Biomass Valoriz. 3, 435-442 (2012)

16. INEC: Análisis del Sistema Agroalimentario del Banano en el Ecuador. http://www.ecuadorencifras.com/sistagroalim/pdf/Banano. pdf (2010). Accessed 23 Oct 2014

17. INEC: Visulizador de Estadísticas Agropecuarias del Ecuador. http://200.110.88.44/lcds-samples/testdrive-remoteobject/main. html\#app=dbb7\&9270-selectedIndex=1 (2013). Accessed 15 Mar 2014

18. MAGAP: Sistema de Información Nacional de Agricultura, Ganadería, Acuacultura y Pesca. http://sinagap.agricultura.gob. ec/banano-2 (2013). Accessed 15 Mar 2014

19. Carvajal-Barriga, E.J., Guamán-Burneo, C., Portero-Barahona, P., Salas, E., Tufiño, C., Bastidas, B.: Biomass now-sustainable growth and use. In: Matovic, M.D. (ed.) InTech, pp. 265-284 (2013)

20. Sánchez, J., Sánchez, F., Curt, M.D., Fernández, J.: Assessment of the bioethanol potential of prickly pear (Opuntia ficus-indica (L.) Mill.) biomass obtained from regular crops in the province of Almeria (SE Spain). Isr. J. Plant Sci. 60, 301-318 (2012)

21. López-Rodríguez, F., Atanet, C.P., Blázquez, F.C., Celma, A.R.: Spatial assessment of the bioenergy potential of forest residues in the western province of Spain, Caceres. Biomass Bioenergy 33, 1358-1366 (2009)

22. MAGAP: Geoportal del agro ecuatoriano. http://geoportal.magap. gob.ec/ (2014). Accessed 12 May 2014

23. Gobierno Provincial Autónomo de El Oro: Geoportal. Sistema de Información Provincial. http://geo.eloro.gob.ec/descargas/ (2014). Accessed 12 May 2014

24. CONELEC: Geoportal. Catálogo de mapas. Subestaciones. http:// geoportal.conelec.gob.ec/visor/index.html (2014). Accessed 19 Mar 2014 
25. IGM: Cartografía de libre acceso. http://www.geoportaligm.gob. ec/portal/index.php/descargas/cartografia-de-libre-acceso/ (2014). Accessed 15 Mar 2014

26. Voivontas, D., Assimacopoulos, D., Koukios, E.G.: Aessessment of biomass potential for power production: a GIS based method. Biomass Bioenergy 20, 101-112 (2001)

27. Scarlat, N., Martinov, M., Dallemand, J.-F.: Assessment of the availability of agricultural crop residues in the European Union: potential and limitations for bioenergy use. Waste Manag. 30, 1889-1897 (2010)

28. Höhn, J., Lehtonen, E., Rasi, S., Rintala, J.: A Geographical Information System (GIS) based methodology for determination of potential biomasses and sites for biogas plants in southern Finland. Appl. Energy 113, 1-10 (2014)

29. CONELEC: Participación de los generadores de energía eléctrica producida con Recursos Energéticos Renovables No Convencionales (Codificación Regulación No. CONELEC 001/13), http://www.conelec.gob.ec/normativa_detalle.php?cd_norm=753 (2013). Accessed 20 June 2014

30. NREL: Standard Procedures for Biomass Compositional Analysis. http://www.nrel.gov/biomass/analytical_procedures.html (2008). Accessed 2 Mar 2015

31. Sing, J., Panesar, B., Sharma, S.: Energy potential through agricultural biomass using geographical information system-a case study of Punjab. Biomass Bioenergy 32, 301-307 (2007)

32. Lovett, A.A., Sünnenberg, G.M., Richter, G.M., Dailey, A.G., Riche, A.B., Karp, A.: Land use implications of increased biomass production identified by GIS-based suitability and yield mapping for Miscanthus in England. BioEnergy Res. 2, 17-28 (2009)

33. Dahal, K.R., Chow, T.E.: A GIS toolset for automated partitioning of urban lands. Environ. Model. Softw. 55, 222-234 (2014)

34. Sánchez, J.: Localización óptima de una planta de bioetanol a partir de tubérculos de pataca (Helianthus tuberosus L.) en la cuenca del Duero, PhD Dissertation, Universidad Politécnica de Madrid (2013)

35. Nguyen, T.L.T., Gheewala, S.H., Garivait, S.: Full chain energy analysis of fuel ethanol from cassava in Thailand. Environ. Sci. Technol. 41, 4135-4142 (2007)
36. Oliveira, L., Cordeiro, N., Evtuguin, D.V., Torres, I.C., Silvestre, A.J.D.: Chemical composition of different morphological parts from "Dwarf Cavendish" banana plant and their potential as a non-wood renewable source of natural products. Ind. Crops Prod. 26, 163-172 (2007)

37. Saraiva, A., Acordi, E., Lea, L., Pereira, E., Alves, V., Furtado, A., Gomes, A., Freire, M., do Carmo, L., Fernandes, G.: Potentials for utilization of post-fiber extraction waste from tropical fruit production in brazil-the example of banana pseudo-stem. Int. J. Environ. Bioenergy 4, 101-119 (2012)

38. Cordeiro, N., Belgacem, M., Torres, I., Moura, J.C.V.: Chemical composition and pulping of banana pseudo-stems. Ind. Crops Prod. 19, 147-154 (2004)

39. IRENA: Renewable Power Generation Costs in 2014. http:// www.irena.org/DocumentDownloads/Publications/IRENA_RE_ Power_Costs_2014_report.pdf (2015). Accessed 12 Feb 2015

40. INEC: Información ambiental en hogares. http://www.ecuador encifras.gob.ec/documentos/web-inec/Encuestas_Ambientales/ Ambientales2012junio/Presentacio_Junio2012.pdf (2012). Accessed 17 Apr 2015

41. INEC: Total de hogares particulares con personas presentes por área; según provincia y cantón (2010). http://www.inec.gob.ec/ tabulados_CPV/5_PROV_CANT_AREA_VIV_HOG.xls. Accessed 17 Apr 2015

42. FAO: Análisis de costos de producción de biocombustible en Perú: Una dimensión social (2010). http://www.fao.org/docrep/ 013/i1708s/i1708s.pdf. Accessed 12 Feb 2015

43. IRENA: Renewable Energy Costs (2012). http://costing.irena. org/technology-costs/transportation/bioethanol.aspx. Accessed 12 Feb 2015

44. Amoo-Gottfried, K., Hall, D.: A biomass energy flow chart for Sierra Leone. Biomass Bioenergy. 16, 361-376 (1999)

45. Jingura, R.M., Matengaifa, R.: The potential for energy production from crop residues in Zimbabwe. Biomass Bioenergy. 32, 1287-1292 (2008) 